\title{
Kapitat erotyczny składową kapitału relacyjnego organizacji
}

\author{
Dr Marzena Syper-Jędrzejak iD \\ Uniwersytet Łódzki, Wydział Zarządzania \\ Katedra Zarządzania Zasobami Ludzkimi
}

\section{Wprowadzenie}

Etymologicznie słowo „kapitał” związane jest z łacińskim przymiotnikiem „capitale”, który koresponduje z rzeczownikiem „caput” oznaczającym „głowę”. Pierwotnie słowo to wykorzystywane było do opisania pożyczonej lub niezbędnej do rozpoczęcia działalności gospodarczej kwotyl. Współcześnie „kapitał” to jedna z podstawowych kategorii ekonomicznych, znajdujących zastosowanie zarówno w makro-, jak i mikroekonomii. W zależności od przyjętego kryterium podziału w ekonomii mówi się między innymi o kapitale realnym i finansowym, fizycznym i niematerialnym czy własnym i obcym² ${ }^{2}$.

Termin „kapitał” jest bliski także naukom o zarządzaniu (i jakości). W odniesieniu do działalności przedsiębiorstwa wyróżnia się zwykle trzy rodzaje kapitału ${ }^{3}$ : rzeczowy (majątek produkcyjny), pieniężny oraz ludzki, będący jednocześnie składową kapitału intelektualnego organizacji. Interdyscyplinarność zarządzania sprawia jednak, że w obszarze zainteresowania specjalistów od organizacji znajdują się też odmienne „formy” kapitału, zwykle badane i analizowane przez przedstawicieli innych nauk społecznych. Dlatego też zarządzanie interesuje się (przykładowo) kapitałem psychologicznym, pod pojęciem którego psychologowie rozumieją określony zasób wewnętrzny jednostki, obejmujący przekonanie o własnej skuteczności, optymizm, nadzieję oraz prężność ${ }^{4}$, czy kapitałem

1 E. Cannan, Early history of the term capital, „Quarterly Journal of Economics” 1921, no. 35, s. 469-481; K. Marchewka, Główne nurty w teorii kapitału, „Ruch Prawniczy, Ekonomiczny i Socjologiczny" 2000, nr 2, s. 105.

2 K. Janasz, Kapitat jako podstawa rozwoju przedsiębiorstwa, „Studia i Prace Wydziału Nauk Ekonomicznych i Zarządzania" 2008, nr 1, s. 69-72.

3 S. Zając, Kapitat rzeczowy a teoria nauk o zarządzaniu, [w:] P. Lenik (red.), Zarzqdzanie organizacjami, Państwowa Wyższa Szkoła Zawodowa im. Stanisława Pigonia w Krośnie, Krosno 2018, s. 183.

4 A. Lipińska-Grobelny, I. Pawlak, Kapitał psychologiczny a zadowolenie z sytuacji zawodowej absolwentów psychologii, „Teraźniejszość - Człowiek - Edukacja” 2018, nr 2(82), s. 87. 
symbolicznym, obejmującym - zgodnie z ujęciem socjologa Bourdieu - kapitał ekonomiczny, społeczny i kulturowy ${ }^{5}$. W naukach o zarządzaniu pojawia się także pojęcie kapitału relacyjnego - na użytek niniejszego opracowania traktowanego jako zdolność nawiązywania kontaktów przez pracowników z otoczeniem gospodarczym, działań na rzecz budowania reputacji i marki firmy, zabiegania o lojalność klientów itp. ${ }^{6}$ Jako taki, kapitał relacyjny powinien być uwzględniany w strategii organizacji i w koncepcji rozwoju jej potencjału.

Jednak jak dotąd $\mathrm{w}$ rodzimym piśmiennictwie z obszaru zarządzania nie znalazły się opracowania poświęcone kapitałowi erotycznemu (z pojedynczymi wyjątkami ${ }^{8}$ ), który, czego dowodzi twórczyni koncepcji kapitału erotycznego - Hakim, odgrywa znaczącą rolę w organizacji. Zdaniem Hakim kapitał erotyczny jest jednym z czynników kształtujących relacje społeczne w miejscu pracy, stanowi jedno z kryteriów (często nieuświadomione) oceny kandydata do zatrudnienia oraz pracownika i determinuje wysokość wynagrodzenia9.

Powyżej wskazany niedostatek opracowań poświęconych kapitałowi erotycznemu i jego roli w organizacji stał się zasadniczą przesłanką do podjęcia tej tematyki w niniejszym opracowaniu. Celem pracy jest wykazanie, że kapitał erotyczny pracowników jest elementem kapitału relacyjnego organizacji i jako taki może przynosić jej korzyści. Kształtowanie kapitału erotycznego powinno być zatem przedmiotem „zainteresowania” nie tylko jednostki, która tym kapitałem dysponuje, ale i kadry zarządzającej.

Opracowanie ma charakter eksploracyjny i teoretyczny. Powstało na podstawie dostępnych (tradycyjnych oraz internetowych) publikacji poświęconych kapitałowi erotycznemu. Sięgnięto głównie do opracowań psychologów i socjologów. Studiami literaturowymi objęto opracowania polsko- i anglojęzyczne poświęcone kapitałowi erotycznemu i jego składowym oraz koncepcji kapitału relacyjnego. Informacji poszukiwano metodą kuli śnieżnej, wychodząc od pojęcia kapitału erotycznego (seksualnego) oraz kapitału erotycznego pracownika i kapitału erotycznego w biznesie. Jako że reprezentatywność

5 P. Bourdieu, The forms of capital, „Cultural Theory: An anthology” 2011, no. 2011, s. 81-93.

6 W. Danielak, Kształtowanie kapitału relacyjnego w małym i średnim przedsiębiorstwie, Wydawnictwo Uniwersytetu Ekonomicznego we Wrocławiu, Wrocław 2012, s. 16-17.

7 J. Penc, Projektowanie strategii przedsiębiorstwa, „Organizacja i Kierowanie” 1993, nr 2(72), S. 42.

8 Por: E. Paprzycka, D. Orlik, Czy wygląd ma znaczenie? Kapitał seksualny a sukces rekrutacyjny w opiniach kobiet i mężczyzn, „Acta Universitatis Lodziensis. Folia Sociologica” 2015, nr 55, s. 5-21; I. Ślęzak-Niedbalska, Niuanse atrakcyjności. Co to znaczy być atrakcyjnq wedtug pracownic agencji towarzyskich?, „Acta Universitatis Lodziensis. Folia Sociologica” 2016, nr 5, s. 103-117; G. Kamecka, Klasa, którq̨ kochamy. Klasowe mechanizmy funkcjonowania rynków matżeńskich, „Młoda Humanistyka” 2019, nr 1(14), s. 1-29.

9 C. Hakim, Erotic Capital, „European Sociological Review” 2010, no. 5, s. 509-510. 
danych wyłonionych za pomocą tej procedury można podać w wątpliwość, jest ona używana przede wszystkim do celów eksploracyjnych ${ }^{10}$, co jest zbieżne $\mathrm{z}$ charakterem niniejszego opracowania.

\section{Koncepcja kapitału erotycznego Hakim}

Jak zaznaczono we wprowadzeniu, pojęcia „kapitał erotyczny” czy „kapitał seksualny” nie są powszechnie stosowane w naukach społecznych. Terminy „kapitał erotyczny” i „kapitał seksualny” pojawiły się w pracach Martina i George’a11 oraz Greena $^{12}$ jako wyjaśniające zachowania seksualne człowieka w kontekście stratyfikacji społecznej. Termin pojawia się także u Brooksa ${ }^{13}$, Farrera ${ }^{14}$, Weinberga i Williamsa ${ }^{15}$, głównie jako element analizy percepcji transseksualizmu lub opisu przemysłu erotycznego czy turystyki erotycznej. Wydaje się jednak, iż koncepcja kapitału erotycznego (seksualnego), jako rozległego pojęciowo konstruktu wykraczającego poza samą tylko atrakcyjność seksualną, została spopularyzowana dopiero przez Hakim ${ }^{16}$.

Idea Hakim zakłada, że kapitał erotyczny składa się z siedmiu komponentów, przy czym znaczenie poszczególnych aspektów zmienia się w czasie i jest zależne od norm charakterystycznych dla danej społeczności. Na kapitał erotyczny człowieka składają się ${ }^{17}$ :

- piękno - traktowane tutaj jako symetryczność i ujednolicony koloryt twarzy oraz preferowane w naszym społeczeństwie wyznaczniki urody, takie jak białe zęby, duże oczy i usta; zdaniem Hakim piękno twarzy jest egzemplifikacją

10 E. Babbie, Podstawy badań społecznych, Wydawnictwo Naukowe PWN, Warszawa 2004, s. 205; K. Jabłońska, A. Sobieraj, Metodyka dobierania próby badawczej w naukach społecznych, „Bezpieczeństwo i Technika Pożarnicza” 2013, nr 32, s. 34-35.

11 J.L. Martin, M. George, Theories of Sexual Stratification: Toward an Analytics of the Sexual Field and a Theory of Sexual Capital, „Sociological Theory” 2006, no. 24, s. 107-132.

12 A.I. Green, The social organisation of desire: the sexual fields approach, „Sociological Theory" 2008, no. 26, s. 25-50.

13 S. Brooks, Unequal Desires: Race and Erotic Capital in the Stripping Industry, SUNY Press, New York 2010.

$14 \mathrm{~J}$. Farrer, A foreign adventurer's paradise? Interracial sexuality and alien sexual capital in reform era Shanghai, „Sexualities” 2010, no. 1(13), s. 69-95.

15 M. Weinberg, C.J. Williams, Men sexually interested in transwomen (MSTW): Gendered embodiment and the construction of sexual desire, „The Journal of Sex Research” 2010, no. 4(47), s. 374-383.

16 C. Hakim, Erotic...; C. Hakim, Erotic Capital. The power of attraction in the boardroom and the bedroom, Basic Books, New York 2011.

17 C. Hakim, Erotic... s. 500-501; E. Paprzycka, D. Orlik, Czy wygląd ma znaczenie?..., s. 7. 
urody i zawsze jest doceniane; piękno rozpoznajemy instynktownie, nie istnieje bowiem jedna pełna, kategorycznie ustalona definicja urody ${ }^{18}$;

- atrakcyjność seksualna - to sposób prezentowania ciała, czyli poruszania się, mówienia, gestykulowania, zwykle osadzony w kontekście płci (czyli będący de facto sposobem prezentowania swojej kobiecości albo męskości);

- atrakcyjność społeczna - dotyczy umiejętności społecznych człowieka, które wpływają na jakość realizowanych przez niego interakcji, sprawiając, że dana osoba wzbudza sympatię otoczenia, jest postrzegana jako charyzmatyczna, atrakcyjna, pociągającą i pożądana, między innymi towarzysko; atrakcyjność społeczna jest zatem tym, co opisuje się jako „wdzięk”, „czar”, „grację”;

- żywiołowość - to komponent związany z cechami strukturalnymi jednostki, z jej temperamentem, sprawnością fizyczną, poziomem energii; zdaniem Hakim osoby obdarzone wysoką energią życiową, dynamiczne w zachowaniu, są postrzegane jako bardziej atrakcyjne, pełne radości życia;

- prezencja - wizerunek zewnętrzny człowieka, kreowany przez noszone ubrania, fryzurę, stosowany makijaż, używane perfumy, a także biżuterię, dodatki, tatuaże, modyfikacje ciała itp.;

- seksualność - element kapitału erotycznego przejawiający się w obszarze życia intymnego (rozumiany jako umiejętność usatysfakcjonowania partnera/ partnerki w relacji seksualnej);

- płodność - zdolność do płodzenia, a w przypadku kobiet także wydania na świat zdrowego potomstwa (element kapitału erotycznego wysoko wartościowany w tych społeczeństwach, w których atrakcyjność człowieka wyznacza posiadanie przez niego dzieci - w społeczeństwach zachodnich płodność ma obecnie małe znaczenie poza relacją rodzinną, partnerską).

Wydaje się, iż zaproponowane przez Hakim kategorie nie są do końca rozłączne. Żywiołowość, jako pojęcie odnoszące się do dynamiki zachowań, jest jednocześnie elementem atrakcyjności seksualnej (czyli sposobu poruszania się i gestykulowania), podobnie jest z zakresem treściowym atrakcyjności seksualnej i społecznej (sposób prezentowania swojej kobiecości czy męskości należy także zaliczyć do szerokiego wachlarza działań składających się na osobisty wdzięk czy czar).

Oczywiste jest, iż kapitał erotyczny odgrywa fundamentalną rolę przy wyborze partnera czy małżonka. Zdaniem Hakim nabiera także coraz większego znaczenia w takich dziedzinach jak: media, polityka, reklama, sport czy sztuka. Jest też związany z różnego rodzaju aktywnościami podejmowanymi przez uczestników rynku pracy (z wyjątkiem dwóch ostatnich komponentów, które mają znaczenie

18 N. Etcoff, Przetrwają najpiękniejsi. Wszystko, co nauka mówi o ludzkim pięknie, Wydawnictwo CiS, Wydawnictwo W.A.B, Warszawa 2002. 
zasadniczo tylko w relacjach osobistych). W odniesieniu do szeroko rozumianej sfery zatrudnienia kapitał seksualny ${ }^{19}$ :

- „bierze udział” w kształtowaniu relacji międzyludzkich w miejscu pracy;

- jest jednym z czynników decydujących o wysokości wynagrodzenia (im wyższy poziom kapitału erotycznego, tym wyższe dochody);

- „pomaga” w wykonywaniu zawodów wymagających częstych kontaktów interpersonalnych;

- jest jednym z predyktorów sukcesu zawodowego.

\section{Kapitał erotyczny pracowników jako składnik kapitału relacyjnego organizacji}

Skrótowo przedstawione powyżej rozważania Hakim pokazują rolę kapitału erotycznego jednostronnie - z punktu widzenia jednostki (osoby), będącej „właścicielem” tego kapitału. Istotne wydaje się jednak spojrzenie na kapitał erotyczny (reprezentowany przez kandydatów do pracy oraz osoby zatrudnione) przez pryzmat organizacji. Z tego punktu widzenia charakterystyki poszczególnych składowych kapitału erotycznego „wpisują się” nie tylko w ideę kapitału symbolicznego jednostki, ale i koncepcję kapitału społecznego oraz relacyjnego organizacji, które stanowią z kolei o kapitale intelektualnym instytucji jako całości.

Kapitał erotyczny - głównie poprzez atrakcyjność społeczną - odgrywa znaczącą rolę w inicjowaniu i podtrzymywaniu interakcji interpersonalnych. Jest zatem pomocny we wszelkich kontaktach wewnątrzorganizacyjnych oraz kontaktach z podmiotami zewnętrznymi. Atrakcyjność społeczna sprzyja prowadzeniu rozmów z kandydatami do pracy, ale i wszystkimi innymi kooperantami. Z tego punktu widzenia kapitał erotyczny jest jednym ze źródeł kapitału społecznego, który można utożsamić z pojęciem kapitału relacyjnego ${ }^{20}$. W organizacji kapitał społeczny jest warstwą zachowań, tworzoną jako „mieszanka” konfrontacji współpracowników i ich wzajemnego wspierania się, stając się dźwignią przedsiębiorczości ${ }^{21}$. Przedsiębiorstwa o wysokim poziomie kapitału społecznego, dzięki płynnemu przepływowi informacji, są predestynowane do osiągania wyższej innowacyjności, zyskując przewagę nad

19 C. Hakim, Erotic..., s. 507-510.

20 Por. K. Perechuda, I. Chomiak-Orsa, Znaczenie kapitału relacyjnego we współczesnych koncepcjach zarzq̨dzania, „Zarządzanie i Finanse” 2013, nr 4, s. 293-307.

21 W. Dyduch, Kapitał społeczny organizacji pożywka dla przedsiębiorczości i innowacyjności, 2001, http://www.zti.com.pl/instytut/pp/referaty/ref42_full.html (dostęp: 17.06.2013). 
konkurentami ${ }^{22}$. Jeśli zatem traktować kapitał społeczny jako cechy organizacji lub jednostek, które kreują efekty zewnętrzne dla całej grupy/wspólnoty, to jest on również kapitałem relacyjnym, czyli zasobami związanymi z umiejętnością tworzenia relacji międzyludzkich, nawiązywania oraz podtrzymywania bliskich i trwałych związków czy budowania sieci społecznej23. Może, jako taki, zostać włączony do strategii personalnej organizacji i rozwoju kultury organizacyjnej, kształtowanej w kierunku akceptacji oraz jak najlepszego wykorzystania zasobów ludzkich ${ }^{24}$.

W takim ujęciu kapitał relacyjny dotyka pojęcia networkingu, czyli procesu wymiany informacji, zasobów, wzajemnego poparcia i możliwości, tworzonych dzięki korzystnej sieci wzajemnych kontaktów ${ }^{25}$. Członkowie organizacji dysponujący wysokim kapitałem relacyjnym, kreują korzyści dla partnerów tworzących sieć relacyjną. Do korzyści takich można zaliczyć zwiększenie aprobaty otoczenia dla działań biznesowych, utrwalanie pozytywnego wizerunku firmy na rynku, stworzenie solidnych podstaw do wykreowania wysokiej reputacji (co znajduje odzwierciedlenie w korzyściach finansowych organizacji), skuteczniejsze pozyskiwanie zasobów niezbędnych do prowadzenia działalności oraz pozyskiwanie i kreowanie unikatowych zasobów ${ }^{26}$.

Zestawiając obszary kapitału relacyjnego z poszczególnymi komponentami budującymi kapitał erotyczny (tabela 1), można zauważyć, że niektóre z jego składowych odgrywają znaczącą rolę w tym procesie, a inne mniejszą lub znikomą (np. płodność czy seksualność). Osoby dysponujące takim kapitałem wywierają silny wpływ na swoje otoczenie i mogą aktywnie wykorzystywać go w celu zdobycia pożądanych zasobów.

22 J. Przybysz, Kapitat społeczny a poziom innowacyjności małych i średnich przedsiębiorstw (MSP), „Optimum. Studia Ekonomiczne” 2011, nr 5(20), s. 208.

23 K. Perechuda, I. Chomiak-Orsa, Znaczenie kapitału relacyjnego..., s. 293-307.

24 W. Harasim, Zarządzanie zasobami ludzkimi i kapitałem ludzkim, „Zeszyty Naukowe Wyższej Szkoły Promocji w Warszawie" 2013, nr 3, s. 41.

25 J. Wróbel, Geneza rozwoju kapitału intelektualnego i jego struktura, [w:] M. Cisek (red.), Kapitat relacyjny w nowoczesnej gospodarcze, Wydawnictwo Studio Emka, Warszawa 2009, s. $16-17$.

26 I. Mendryk, Kapitat relacyjny w identyfikowaniu luki kompetencyjnej przedsiębiorstwa, [w:] A. Sitko-Lutek (red.), Polskie firmy wobec globalizacji, Wydawnictwo Naukowe PWN, Warszawa 2007, s. 111. 
Tabela 1. Komponenty kapitału erotycznego odgrywające szczególną rolę w kreowaniu relacji

\begin{tabular}{|l|l|}
\hline \multicolumn{1}{|c|}{ Wybrane obszary kapitału relacyjnego } & \multicolumn{1}{|c|}{$\begin{array}{c}\text { Komponenty kapitału } \\
\text { erotycznego }\end{array}$} \\
\hline $\begin{array}{l}\text { Nawiązywanie kontaktu (z kontrahentami, klientami } \\
\text { zewnętrnymi i wewnętrznymi, interesariuszami, } \\
\text { przedstawicielami środowisk lokalnych, samorządowych, } \\
\text { konkurentami, ekspertami) }\end{array}$ & $\begin{array}{l}\text { Piękno, prezencja, } \\
\text { atrakcyjność seksualna }\end{array}$ \\
\hline $\begin{array}{l}\text { Podtrzymywanie relacji interpersonalnych (klienci, eksperci, } \\
\text { kontrahenci itp.) }\end{array}$ & $\begin{array}{l}\text { Żywiołowość, atrakcyjność } \\
\text { społeczna, atrakcyjność } \\
\text { seksualna, prezencja }\end{array}$ \\
\hline $\begin{array}{l}\text { Dzielenie się zasobami (informacja, wiedza, wsparcie) } \\
\text { z partnerami interakcji }\end{array}$ & $\begin{array}{l}\text { Atrakcyjność społeczna, } \\
\text { żywiołowość }\end{array}$ \\
\hline $\begin{array}{l}\text { Tworzenie i podtrzymywanie sieci powiązań za pośrednictwem } \\
\text { mediów i osobistego kontaktu }\end{array}$ & $\begin{array}{l}\text { Żywiołowość, atrakcyjnośćc } \\
\text { spoteczna }\end{array}$ \\
\hline $\begin{array}{l}\text { Utrwalanie pozytywnego wizerunku firmy/marki, zwiększanie } \\
\text { aprobaty otoczenia dla dziatań organizacji }\end{array}$ & $\begin{array}{l}\text { Prezencja, atrakcyjność } \\
\text { spoteczna, żywiołowość }\end{array}$ \\
\hline
\end{tabular}

Źródło: opracowanie własne.

\section{Kapitat erotyczny w tworzeniu i utrzymywaniu relacji}

Kapitał społeczny (czy) relacyjny traktowany jest jako składowa kapitału intelektualnego i jako taki (w postaci wiedzy, informacji, własności intelektualnej i doświadczenia) może zostać przetworzony na dobro materialne ${ }^{27}$. Kapitał erotyczny, jako czynnik kapitału relacyjnego, wpływa na tzw. pierwsze wrażenie, które często ma decydujące znacznie dla znajomości, a także przesądza o tym, czy do interakcji w ogóle dojdzie. Informacje o fizycznej atrakcyjności, wdzięku i prezencji stanowią ważny element procesu komunikowania, oddziałując tym samym na wynik rozmów, siłę argumentów i możliwości wywierania wpływu na rozmówcę ${ }^{28}$.

Szczególnie widoczny jest wpływ kapitału erotycznego na sukces w procesie poszukiwania pracy i rekrutacji, co akurat znajduje swoje odzwierciedlenie w świadomości kandydatów do pracy. Badania polskie wskazują, że w powszechnej opinii osobom atrakcyjnym łatwiej zdobyć pracę: osoby urodziwe częściej są zapraszane na rozmowę kwalifikacyjną na podstawie zdjęcia w CV, osoby szczupłe łatwiej uzyskują zatrudnienie, osoby atrakcyjne, ale o niskich kompetencjach zawodowych są i tak dobrze oceniane przez rekruterów. Zdaniem badanych piękno i atrakcyjność seksualna w kontekście rozmowy kwalifikacyjnej miały słabsze

27 A. Jashapara, Zarzq̨dzanie wiedzq, Polskie Wydawnictwo Ekonomiczne, Warszawa 2014, s. 85.

28 E. Paprzycka, D. Orlik, Czy wygląd ma znaczenie?..., s. 5-6. 
oddziaływanie niż atrakcyjność społeczna, żywiołowość czy prezencja ${ }^{29}$. Inne ustalenia także potwierdzają istotną rolę fizycznej atrakcyjności kandydata dla decyzji rekruterów, obok takich cech jak sumienność i stabilność emocjonalna ${ }^{30}$. Interesujące są zwłaszcza prowadzone w Argentynie badania przywoływane przez Hakim, w których wykazano, że efekt ten dał się zaobserwować także podczas rozmów telefonicznych prowadzonych z kandydatami do pracy (co wskazuje na siłę oddziaływania ich atrakcyjności seksualnej, społecznej, ewentualnie żywiołowości) ${ }^{31}$.

Kapitał erotyczny, co wynika z samej złożoności tego konstruktu, jest trudno mierzalny, a wpływ jego składowych na sukces zawodowy czy finansowy niełatwo wyizolować. Pojawiają się jednak próby oszacowania siły jego wpływu, chociażby na wysokość zarobków. Badania Hamermesha i Biddle’a w latach dziewięćdziesiątych XX wieku koncentrowały się na próbie oszacowania wysokości tzw. premii za piękno w zarobkach kobiet i mężczyzn w Stanach Zjednoczonych. Badacze potwierdzili prawidłowość, że zwykli ludzie zarabiają mniej niż przeciętnie wyglądający ludzie, którzy zarabiają mniej niż dobrze wyglądający mężczyźni i kobiety. „Premia” za piękno wahała się od 1\% do maksymalnie 13\% (dla kobiet), podczas gdy „kara” za zwykły wygląd wahała się od 1\% do 10\%. Działo się to bez względu na różnice w inteligencji czy pochodzeniu badanych ${ }^{32}$.

Podjęto także próby oszacowania wpływu poszczególnych składowych kapitału erotycznego. I tak całkowity wpływ atrakcyjności na wysokość osiąganych dochodów jest mniej więcej równy wpływowi kwalifikacji edukacyjnych czy pewności siebie, ale znacznie mniejszy niż wpływ inteligencji ${ }^{33}$. Analizy badań podłużnych prowadzonych w Stanach Zjednoczonych wskazują na istnienie związku pomiędzy takimi cechami jak wysoki wzrost i prawidłowa masa ciała a wysokością płacy kobiet - zarówno w zawodach fizycznych, jak i wyspecjalizowanych. Wyższe kobiety dostają „premię” za swój wzrost, podczas gdy kobiety z nadwagą podlegają znacznym „karom” finansowym (średnio jest to $2,4 \%$ rocznie). Wśród kobiet o ponadprzeciętnych kwalifikacjach „specjalistycznych” wpływ atrybutów

29 Tamże, s. 20.

30 S. Baert, L. Decuypere, Better sexy than flexy? A lab experiment assessing the impact of perceived attractiveness and personality traits on hiring decisions, „Applied Economics Letters” 2014, no. 21(90), s. 597-601.

31 C. Hakim, Erotic Capital. The power of attraction..., s. 171; R. Asghar, Erotic Capital in Danish Society and Labour Market, https://rucforsk.ruc.dk/ws/portalfiles/portal/63733377/EROT IC_CAPITAL_FINAL (dostęp: 12.12.2019).

32 D.S. Hamermesh, J.E. Biddle, Beauty and the labor market, „American Economic Review” 1994, no. 84, s. 1174-1194; C. Hakim, Erotic..., s. 509.

33 T.A. Judge, C. Hurst, L.S. Simon, Does it pay to be smart, attractive, or confident (or all three)? Relationships among general mental ability, physical attractiveness, core self-evaluations, and income, „Journal of Applied Psychology” 2009, no. 94, s. 742-755. 
fizycznych na płace jest jednak nieznaczny ${ }^{34}$. Podobną prawidłowość, tj. istnienie „premii” za fizyczną atrakcyjność dla kobiet, ale nie w przypadku mężczyzn, wskazał French ${ }^{35}$. Nie tylko piękno wpływa na wysokość zarobków - znaczenie ma także „zadbanie” (czyli prezencja) oraz „atrakcyjna, pociągająca osobowość”, czyli atrakcyjność społeczna i seksualna ${ }^{36}$.

Powyższe rozważania prowadzą do konkluzji, że zdolność człowieka do tworzenia relacji i sieci powiązań (zarówno w życiu osobistym, jak i zawodowym) jest powiązana z jego kapitałem erotycznym. Wydaje się to zauważalne w szeroko pojętej działalności handlowej. Pracownicy (głównie pracownice) handlu i obsługi klienta wykorzystują swój kapitał erotyczny, aby dobrze zaprezentować się klientowi, nawiązać kontakt („być wesołym”, „skomplementować” klienta, znaleźć wzajemne podobieństwa itp.), zainteresować go produktem/usługą, doradzać i skłonić do zakupu oraz zachęcić do ponownego odwiedzenia sklepu ${ }^{37}$.

Okazuje się, że nawet podczas spotkania z serwisantem czy załatwiania reklamacji pracownik dysponujący kapitałem erotycznym jest w stanie wpłynąć na reakcję konsumenta (jego zadowolenie, postrzeganie jakości usługi itp.). W przypadku klienta przekonanego o własnej nieatrakcyjności efekt będzie odwrotny - konsumenci postrzegający się jako nieatrakcyjni mogą reagować negatywnie na atrakcyjność fizyczną przedstawiciela handlowego, serwisanta czy pracownika działu reklamacji ${ }^{38}$.

Sprawa odbioru kapitału erotycznego w pracy jest niejednoznaczna. Wywiady prowadzone wśród pracowników i menedżerów branży hotelarskiej wskazują, że kapitał erotyczny pracownika przekłada się na wzrost sprzedaży, większą liczbę klientów czy deklarowany zamiar ponownego skorzystania z usługi. Jednak odnotować można także jego negatywne konsekwencje dla organizacji - mowa tu o narastającym poczuciu niesprawiedliwości czy postawach cynicznych wśród pracowników ${ }^{39}$.

34 A. Mitra, Effects of physical attributes on the wages of males and females, „Applied Economics Letters" 2001, no. 8, s. 731-735.

35 M.T. French, Physical appearance and earnings: further evidence, „Applied Economics” 2002, no. 34, s. 569-572.

36 I.C. Beulaygue, Flirting with Erotic Capital: Erotic Capital and Labor Market Earnings among Women, 2012, https://scholarlyrepository.miami.edu/oa_theses/359 (dostęp: 19.12.2019).

37 R. Asghar, Erotic Capital in Danish Society..., s. 16.

38 L. Yaoqi, Ch. Zhang, M. Laroche, Is beauty a premium? A study of the physical attractiveness effect in service encounters, „, Journal of Retailing and Consumer Services” 2019, no. 50 , s. $215-225$.

39 A.M. Abubakar, E.T. Anasori, T. Lasisi, Physical attractiveness and managerial favoritism in the hotel industry: The light and dark side of erotic capital, „Journal of Hospitality and Tourism Management" 2018, no. 38, s. 16-26. 
Kapitał erotyczny pracowników (w tym wypadku pracownic) wykorzystuje się także w tworzeniu sieci współzależności i daleko sięgającej współpracy (guanxi) w kulturach azjatyckich (Chiny) ${ }^{40}$.

Istnieją dane, że kapitał erotyczny wpływa na proces negocjacji biznesowych, zarówno w przypadku kobiet (silniej reagujących na atrakcyjnych negocjatorów płci przeciwnej), jak i mężczyzn, co - jak sugeruje Rosenblatt - może mieć implikacje dla praktyki negocjacji charakteryzujących się skrajnym brakiem równowagi sił między stronami ${ }^{41}$. Wydaje się, iż podobny pozytywny efekt może uzyskać firma wysyłająca swoich reprezentantów z wysokim kapitałem erotycznym na branżowe konferencje, targi czy eventy.

\section{Podsumowanie}

Kapitał erotyczny, jako element kapitału intelektualnego organizacji i jednocześnie kapitał relacyjny, może stanowić w dzisiejszych czasach o przewadze konkurencyjnej przedsiębiorstwa, w gospodarce opartej na wiedzy dużego znaczenia nabiera bowiem partnerska współpraca $z$ innymi podmiotami oraz zdolność do tworzenia trwałych związków. Kapitał relacyjny ułatwia wykorzystanie posiadanych kompetencji, dzielenie się wiedzą (czy ryzykiem) oraz tworzenie unikatowych produktów/usług ${ }^{42}$.

Przywoływane w opracowaniu dane i ustalenia wskazują, iż kapitał erotyczny ma znaczenie w nawiązywaniu i podtrzymywaniu relacji - także w aspekcie zawodowym. Dla jednostki niesie to oczywiste korzyści: sukcesy w procesach rekrutacyjnych ${ }^{43}$ czy późniejsze średnio o kilka do kilkunastu procent wyższe zarobki ${ }^{44}$. Niniejsze opracowanie stanowi próbę wyjścia poza tę jednostkową perspektywę i uwzględnienia kontekstu organizacyjnego.

Stan wiedzy dotyczący kapitału relacyjnego jest dość skromny, a dotychczasowe badania empiryczne są fragmentaryczne i niewolne od ograniczeń

40 L. Tang, Gendered and sexualized guanxi: the use of erotic capital in the workplace in urban China, „Asia Pacific Business Review” 2019, no. 4, s. 1-19.

41 T.S. Rosenblatt, The Beauty Premium: Physical Attractiveness and Gender in Dictator Games, „Negotiation Journal” 2008, no. 4(24), s. 465-466.

42 E. Bombiak, Kapitat relacyjny w nowoczesnych organizacjach - istota i pomiar, 2017, https:// repozytorium.uph.edu.pl/bitstream/handle/11331/1430/Bombiak.E.Kapita\%C5\%82 _relacyjny_w_nowoczesnych_organizacjach_-_istota_i_pomiar.pdf?sequence=5 (dostęp: 21.12.2019).

43 Por. E. Paprzycka, D. Orlik, Czy wygląd ma znaczenie...., s. 20; C. Hakim, Erotic..., s. 509-510; S. Baert, L. Decuypere, Better sexy than flexy?..., s. 597-601.

44 Por. D.S. Hamermesh, J.E. Biddle, Beauty..., s.1174-1194; I.C. Beulaygue, Flirting With Erotic Capital... 
koncepcyjno-metodycznych. Obszar ten z pewnością wymaga dalszej eksplora$\mathrm{cji}^{45}$. Jeszcze silniej problem ten dotyka rozważań teoretycznych i badań dotyczących kapitału erotycznego, co stanowi podstawowe ograniczenie niniejszego opracowania. Wydaje się, iż pojęcie kapitału erotycznego pracowników może stanowić jeden z kierunków rozważań w tym kontekście. Kapitał erotyczny jako część kapitału relacyjnego wydaje się mieć znaczenie zwłaszcza w przypadku pracowników zajmujących się szeroko pojętą obsługą klienta (także posprzedażową), wchodzących w skład zespołów negocjacyjnych czy reprezentujących firmę podczas spotkań, konferencji, wydarzeń branżowych i działań wizerunkowych. Niniejsze opracowanie wskazuje na konieczność kontynuowania i pogłębienia takich badań, z uwzględnieniem perspektywy interesów organizacji, a nie tylko sukcesu jednostki. Pojawiają się także nowe pytania, pomijane do tej pory w polskim piśmiennictwie - jak może zostać wykorzystany kapitał erotyczny pracowników w firmowych social mediach i czy będzie on w stanie odgrywać znaczącą rolę w coraz bardziej poszerzającej się wirtualnej przestrzeni.

\section{Bibliografia}

Abubakar A.M., Anasori E., Lasisi T., Physical attractiveness and managerial favoritism in the hotel industry: The light and dark side of erotic capital, „Journal of Hospitality and Tourism Management" 2018, no. 38, s. 16-26.

Asghar R., Erotic Capital in Danish Society and Labour Market, https://rucforsk.ruc.dk/ws/portal files/portal/63733377/EROTIC_CAPITAL_FINAL (dostęp: 12.12.2019).

Babbie E., Podstawy badań społecznych, Wydawnictwo Naukowe PWN, Warszawa 2004.

Baert S., Decuypere L., Better sexy than flexy? A lab experiment assessing the impact of perceived attractiveness and personality traits on hiring decisions, „Applied Economics Letters” 2014, no. 21(90), s. 597-601.

Beulaygue I.C., Flirting with Erotic Capital: Erotic Capital and Labor Market Earnings among Women, 2012, https/scholarlyrepository.miami.edu/oa_theses/359 (dostęp: 19.12.2019).

Bombiak E., Kapitat relacyjny w nowoczesnych organizacjach-istota i pomiar, 2017, https:// repozytorium.uph.edu.pl/bitstream/handle/11331/1430/Bombiak.E.Kapita\%C5\%82 _relacyjny_w_nowoczesnych_organizacjach_-_istota_i_pomiar.pdf?sequence=5 (dostęp: 21.12.2019).

Bourdieu P., The forms of capital, „Cultural Theory: An anthology” 2011, no. 2011, s. 81-93.

Brooks S., Unequal Desires: Race and Erotic Capital in the Stripping Industry, SUNY Press, New York 2010.

Cannan E., Early history of the term capital, „Quarterly Journal of Economics” 1921, no. 35, s. 469-481.

Danielak W., Ksztattowanie kapitału relacyjnego w matym i średnim przedsiębiorstwie, Wydawnictwo Uniwersytetu Ekonomicznego we Wrocławiu, Wrocław 2012.

45 R. Lenart, Kierunki badań nad kapitałem relacyjnym, „Przegląd Organizacji” 2015, nr 7, s. 9. 
Dyduch W., Kapitał społeczny organizacji pożywką dla przedsiębiorczości i innowacyjności, 2001, http://www.zti.com.pl/instytut/pp/referaty/ref42_full.html (dostęp: 17.06.2013).

Etcoff N., Przetrwają najpiękniejsi. Wszystko, co nauka mówi o ludzkim pięknie, Wydawnictwo CiS, Wydawnictwo WAB, Warszawa 2002.

Farrer J., A foreign adventurer's paradise? Interracial sexuality and alien sexual capital in reform era Shanghai, „Sexualities” 2010, no. 1(13), s. 69-95.

French M.T., Physical appearance and earnings: further evidence, „Applied Economics” 2002, no. 34, s. 569-572.

Green A.I., The social organisation of desire: the sexual fields approach, „Sociological Theory” 2008 , no. 26 , s. 25-50.

Hakim C., Erotic Capital, „European Sociological Review” 2010, no. 5, s. 499-518.

Hakim C., Erotic Capital. The power of attraction in the boardroom and the bedroom, Basic Books, New York 2011.

Hamermesh D.S., Biddle J.E., Beauty and the labor market, „American Economic Review” 1994, no. 84, s. 1174-1194.

Harasim W., Zarządzanie zasobami ludzkimi i kapitałem ludzkim, „Zeszyty Naukowe Wyższej Szkoły Promocji w Warszawie" 2013, nr 3, s. 8-43.

Jabłońska K., Sobieraj A., Metodyka dobierania próby badawczej w naukach społecznych, „Bezpieczeństwo i Technika Pożarnicza" 2013, nr 32, s. 31-36.

Janasz K., Kapitat jako podstawa rozwoju przedsiębiorstwa, „Studia i Prace Wydziału Nauk Ekonomicznych i Zarządzania" 2008, nr 1, s. 69-72.

Jashapara A., Zarzq̨dzanie wiedzq, Polskie Wydawnictwo Ekonomiczne, Warszawa 2014.

Judge T.A., Hurst C., Simon L.S., Does it pay to be smart, attractive, or confident (or all three)? Relationships among general mental ability, physical attractiveness, core self-evaluations, and income, „Journal of Applied Psychology” 2009, no. 94, s. 742-755.

Kamecka G., Klasa, którq kochamy. Klasowe mechanizmy funkcjonowania rynków małżeńskich, „Młoda Humanistyka” 2019, nr 1(14), s. 1-29.

Lenart R., Kierunki badań nad kapitałem relacyjnym, „Przegląd Organizacji” 2015, nr 7, s. 9-24.

Lipińska-Grobelny A., Pawlak I., Kapitat psychologiczny a zadowolenie z sytuacji zawodowej absolwentów psychologii, „Teraźniejszość - Człowiek - Edukacja” 2018, nr 2(82) s. 87-101.

Marchewka K., Główne nurty w teorii kapitału, „Ruch Prawniczy, Ekonomiczny i Socjologiczny” 2000, nr 2, s. 105-120.

Martin J.L., George M., Theories of Sexual Stratification: Toward an Analytics of the Sexual Field and a Theory of Sexual Capital, „Sociological Theory” 2006, no. 24, s. 107-132.

Mendryk I., Kapitat relacyjny w identyfikowaniu luki kompetencyjnej przedsiębiorstwa, [w:] A. Sitko-Lutek (red.), Polskie firmy wobec globalizacji, Wydawnictwo Naukowe PWN, Warszawa 2007, s. $116-126$.

Mitra A., Effects of physical attributes on the wages of males and females, „Applied Economics Letters" 2001, no. 8, s. 731-735.

Paprzycka E., Orlik D., Czy wyglą ma znaczenie? Kapitat seksualny a sukces rekrutacyjny w opiniach kobiet i mężczyzn, „Acta Universitatis Lodziensis. Folia Sociologica” 2015, nr 55, s. 5-21.

Penc J., Projektowanie strategii przedsiębiorstwa, „Organizacja i Kierowanie” 1993, nr 2(72), s. $36-48$.

Perechuda K., Chomiak-Orsa I., Znaczenie kapitału relacyjnego we współczesnych koncepcjach zarzq̨dzania, „Zarządzanie i Finanse” 2013, nr 4, s. 293-307.

Przybysz J., Kapitał społeczny a poziom innowacyjności matych i średnich przedsiębiorstw (MSP), „Optimum. Studia Ekonomiczne” 2011, nr 5(20), s. 212-225. 
Rosenblatt T.S., The Beauty Premium: Physical Attractiveness and Gender in Dictator Games, „Negotiation Journal" 2008, no. 4(24), s. 465-481.

Ślęzak-Niedbalska I., Niuanse atrakcyjności. Co to znaczy być atrakcyjnq według pracownic agencji towarzyskich?, „Acta Universitatis Lodziensis. Folia Sociologica” 2016, nr 5, s. 103-117.

Tang L., Gendered and sexualized guanxi: the use of erotic capital in the workplace in urban China, „Asia Pacific Business Review” 2019, no. 4, s. 1-19.

Weinberg M., Williams C.J., Men sexually interested in transwomen (MSTW): Gendered embodiment and the construction of sexual desire, „The Journal of Sex Research” 2010, no. 4(47), s. 374-383.

Wróbel J., Geneza rozwoju kapitału intelektualnego i jego struktura, [w:] M. Cisek (red.), Kapitat relacyjny w nowoczesnej gospodarce, Wydawnictwo Studio Emka, Warszawa 2009, s. 11-23.

Yaoqi L., Zhang Ch., Laroche M., Is beauty a premium? A study of the physical attractiveness effect in service encounters, „Journal of Retailing and Consumer Services” 2019, no. 50, s. 215-225.

Zając S., Kapitat rzeczowy a teoria nauk o zarzqdzaniu, [w:] P. Lenik (red.), Zarzqdzanie organizacjami, Państwowa Wyższa Szkoła Zawodowa im. Stanisława Pigonia w Krośnie, Krosno 2018, s. 183-206.

\section{Streszczenie}

Rozdział poświęcony jest kapitałowi erotycznemu pracowników, traktowanemu jako część kapitału relacyjnego. Celem pracy jest wykazanie, że kapitał erotyczny pracowników może obecnie stanowić o przewadze konkurencyjnej firmy, a rozważania nad nim nie powinny ograniczać się do perspektywy jednostkowej (traktowania kapitału erotycznego tylko jako czynnika osobistego sukcesu). W polskim piśmiennictwie zasadniczo brakuje opracowań poświęconych temu zagadnieniu. Praca ma charakter eksploracyjny i teoretyczny. Powstała na podstawie analizy dostępnych publikacji o kapitale erotycznym, poszukiwanych metodą kuli śnieżnej. Ustalono, że w perspektywie organizacyjnej kapitał erotyczny ma szczególne znaczenie dla nawiązywania i utrzymywania relacji z klientem oraz reprezentowania firmy.

Słowa kluczowe: kapitał erotyczny, kapitał relacyjny, atrakcyjność pracownika

\section{Erotic capital as a component of the relational capital of organization}

\section{Abstract}

The article is devoted to the erotic capital of employees treated as part of relational capital. The purpose of the paper is to show that employees' erotic capital can currently constitute a competitive advantage of a company, and considerations on it should not be limited to an individual perspective (treating erotic capital only as a factor of personal success). There is generally a lack of studies devoted to this issue in Polish literature. The article is exploratory and theoretical. It was created on the basis of an analysis of available publications with erotic capital sought by the snowball method. It has been established that in the organizational perspective, erotic capital is of particular importance for establishing and maintaining relationships with clients and representing the company.

Keywords: erotic capital, relational capital, employee attractiveness 